\title{
Sleep Medicine: Current Challenges and its Future
}

Editor

BARBARA GNIDOVEC STRAŽIŠAR

\section{SLEEP MEDICINE CLINICS}

www.sleep.theclinics.com

Consulting Editor

TEOFILO LEE-CHIONG Jr

September 2021 • Volume 16 • Number 3 